\title{
The Indelible Markers of Twentieth-Century Spanish Antifeminism
}

\author{
Teresa María Ortega López ${ }^{1}$ and Núria Félez Castañé ${ }^{2}$ \\ ${ }^{1}$ Universidad de Granada \\ e-mail: tmortega@ugr.es \\ ORCID iD: https://orcid.org/0000-0002-4486-9715 \\ ${ }^{2}$ Universidad de Granada \\ ORCID iD: https://orcid.org/0000-0001-5515-6588
}

Submitted: 20 July 2019. Accepted: 29 October 2019

\begin{abstract}
In twentieth-century Spain, the conservative political ideology maintained a gender discourse and an ideal of femininity that remained broadly unchanged. The democratic regimes established in the country, first after the reign of Alfonso XIII and then after the Franco dictatorship, did nothing to substantially fragment the country's conservatism with regard to its proponents' view of the function and role that women should fulfil in society. In an attempt to trace the indelible markers of Spanish antifeminism, this article examines three of conservatism's key ideas related to gender: a differentiated consideration of male and female natures; a rejection of feminism; and a conception of the family as the preferred locus for the development of the so-called natural functions of women.
\end{abstract}

KEYWORDS: Gender; Discourse; Conservatism; Women; Antifeminism.

Citation / Cómo citar este artículo: Ortega López, Teresa María and Félez Castañé, Núria (2020) “The Indelible Markers of Twentieth-Century Spanish Antifeminism" Culture \& History Digital Journal, 9 (1): e008. https://doi.org/10.3989/ chdj. 2020.008

RESUMEN: Los marcadores indelebles del antifeminismo español del siglo XX.-En la España del siglo XX, la ideología política conservadora mantuvo un discurso de género y un ideal de feminidad que permaneció prácticamente sin cambios. Los regímenes democráticos establecidos en el país, primero tras el reinado de Alfonso XIII y más tarde tras la dictadura franquista, no hicieron nada para fragmentar de manera sustancial el conservadurismo del país con respecto a la visión de sus proponentes sobre la función y el papel que las mujeres deben cumplir en la sociedad. En un intento por rastrear los marcadores indelebles del antifeminismo español, este artículo examina tres de las ideas clave del conservadurismo relacionadas con el género: una consideración diferenciada de la naturaleza masculina y femenina; un rechazo del feminismo; y una concepción de la familia como el lugar preferido para el desarrollo de las llamadas funciones naturales de las mujeres.

PALABRAS CLAVE: Género; Discurso; Conservadurismo; Mujer; Antifeminismo.

Copyright: (C) 2020 CSIC. This is an open-access article distributed under the terms of the Creative Commons Attribution 4.0 International (CC BY 4.0) License. 


\section{INTRODUCTION}

Twentieth-century Spain witnessed a number of different political systems: a constitutional monarchy where the king actively intervened in political affairs; a republic; the two dictatorships of Miguel Primo de Rivera and Francisco Franco; and a parliamentary monarchy. The country was also the setting for great advances regarding equality. Women won the right to vote, divorce laws were passed, information about birth control and use of contraceptives was made widely available and abortion was decriminalized. A variety of actors, from the Catholic Church to openly antifeminist women's associations, the Sección Femenina - the women's branch of the Falange political movement - and conservative political parties themselves opposed these advances. ${ }^{1}$

The extreme cultural transformation that was taking place in Western societies also gave rise to a growing 'gender uncertainty'. ${ }^{2}$ In Spain during the first third of the twentieth century, the 'antifeminist reaction' came swiftly, only abating slightly in some respects during the period of political transition after the Franco dictatorship. ${ }^{3}$ The different conservative political groups maintained an organicist conception of society with the family located at the core as the fundamental unit, an unwavering defence of the two distinct male and female identities and natures, and a resounding rejection of feminism as a pernicious, revolutionary ideology that could only lead to social disorder and chaos. Despite the fact that antifeminism in this culture had many nuances, these three main ideas underpinned the conservative ideology with regard to gender.

The starting point for this study is the hypothesis that what happened in Spain mirrored what British journalist Nicholas Fraser observed in Italy. There, the old fascist activists of the Mussolini era were ousted from power by a new generation that ostensibly adopted both the forms and the practices of a democracy (Fraser, 2001). In Spain, although the foundations were renewed and rejuvenated during the country's transition to democracy after Franco's death in an attempt to promote a modernizing image in accordance with the new times and demands of a changing society, the ideas of conservatism remained practically unaltered, and although this was not true of the base, it did apply to the leaders.

This presentation of antifeminism examines the points of continuity through some key figures in the configuration and reconfiguration of conservatism, particularly a fundamental conservative figure during the last quarter of the twentieth century: Manuel Fraga Iribarne. Fraga was a minister during the dictatorship, a founding father of the Spanish Constitution of 1978 , leader of the party that declared itself the sociological heir to Franco, the People's Alliance (Alianza Popular or AP), and a follower of the conservatism that emerged in early twentieth-century Spain from the pens of thinkers and politicians, including José María Pemán, ${ }^{4}$ another significant figure in this study. An admirer and great friend of Pemán, Fraga would find in him a framework for his ideas, including with regard to gender. ${ }^{5}$ The figure and representation of what a woman should be as characterized by Pemán, based on Catholic ideas about gender and family combined with modern scientific thinking about the existence of two different natures - one female and the other male - were kept alive by the conservative party during the democracy. ${ }^{6}$

This analysis does not address the party that led the transition to democracy, the Union of the Democratic Centre (Unión de Centro Democrático or UCD), despite the fact that many of its leaders also came from the Franco political elite. Unlike the Franco elites included in this study, the UCD contained more progressive sectors that worked for equality between women and men, with some limitations, from the General Subcommittee on Women's Affairs. After the UCD disbanded in 1983, the staff of the Subcommittee either left politics or continued to work in other parties, including the Spanish Socialist Workers' Party (Partido Socialista Obrero Español or PSOE). Thus, pressure to obtain citizenship rights for women came from the social-democratic sectors, not from the conservative groups in the party (Félez, 2018).

This article examines the ideal of femininity constructed and imposed by a conservatism that - although it varied somewhat as the twentieth century progressed shared some ideological pillars inspired by the same principles for almost one hundred years. This conservatism was characterized by certain indelible markers seen in an emphatic public/private division, the defence of the hetero-patriarchal family as the normative model, the alliance with the Catholic Church and established powers, an obsession with a misunderstood and scarcely untouched meritocracy, and the dismantling of or opposition to particular social policies, all of which frequently forced women to retreat to their position as, fundamentally, reproducers and 'queens of the home'.

\section{THE THEORETICAL FRAMEWORK AND SOURCES}

It has been observed that 'the most solidly established [...] of all collective illusions' is the 'di-vision of the world'. Grounded both in biological and economic differences, the principles of di-vision 'contribute to the very reality of the social order by realizing themselves in bodies' (Bourdieu, 2007, 232). In light of this assertion, 'women' and 'men' are 'categories continually being forged, contested, reworked and reaffirmed' (Davidoff and Hall, 1994 p, 10), as argued by scholars of femininity and masculinity. Equally important in this context is the fact that language is a generative tool that mediates and constitutes reality, rather than being a transparent mirror of it (Bolufer, 1998 p. 14). Through language, the ideals of femininity and masculinity are elaborated, determining experience, influencing behaviour and structuring expectations. For many authors, language is not just a way to represent reality, but acts as a system of meaning, actively intervening in the production of the meanings attributed to the real world, using meanings to organize and make sense of practice (Cabrera, 2006 p, 235). Joan Scott argues something similar, 
considering language a system 'through which meaning is constructed and cultural practices organized and by which, accordingly, people represent and understand their world, including who they are and how they relate to others' (Scott, 1998 p. 34).

Moreover, political cultures are a conglomerate of values, norms, representations and languages that construct collective identities, which in turn are sustained by a particular group memory and produce certain activist or sociable practices (Cenarro and Illion, 2014 p. 16). Once again echoing Scott, political discourse is a constructed network of meanings that contains a particular way of understanding the world and society. This article is specifically interested in an ideal of femininity that shaped a conservative female identity that, while not necessarily interiorized as a whole and/or without criticism from women, served as a corpus of reference. Without denying female agency, the construction of identities depends on the representations created through language, socialization processes and the options available in a given society and at a given time. In this respect, conservatism - like the left - provided Spanish women with a new collective civic identity (Ramos, 2010).

On the basis of the assumptions regarding the social and cultural construction of gender models briefly outlined above, this article investigates the formulations crafted by anti-liberal, conservative and ultramontane political groups for women. This is done through an analysis of the female ideal and the ideas about society articulated by these groups during the early and late twentieth century. These periods - the Second Republic and the transition to democracy - were times of profound, critical transformations for Spanish women in the programmes, discourse, legislation and efforts of the opposition to the government.

The sources for the study include original texts, speeches and various publications by the leading proponents of ideological positions as seemingly different as Maurism, the Patriotic Union (UP), the Spanish Confederation of Autonomous Rights or CEDA, Spanish Restoration (RE), Traditionalist Communion and the Spanish Falange during the early twentieth century, and People's Alliance during the transition to democracy. ${ }^{7}$ As a whole, all of these sources portray women as having a unitary identity based both on Catholic social thinking and the organicist theory of society and the difference between the sexes (Moya, 1984 p. 58), a concept also upheld by the Franco regime.

The starting point for the entire multifaceted Spanish right wing was the conviction that women and men had specific functions and qualities that were complementary and, consequently, unequal. This formulation was rooted in a strong antifeminist sentiment that persisted, without compromise, throughout the twentieth century, thanks in large part to the long Franco dictatorship (Arce, 2005). Due to the combination of the social and political change sparked in Spain by the outbreak of the Civil War and the political and ideological interests of the new Franco regime, a great deal of this discourse and the antifeminist, conservative and androcentric representations forged in the 1920 s and 30 s were to prevail. The Franco dictatorship constructed a discourse for Spanish women indebted to the Vatican literature produced to combat the desires for emancipation and equality of the suffragist movement that was then projected, like a long shadow, onto the political movement that proclaimed itself heir to the dictatorship, the AP. Them reclaimed the female ideal that was crafted at the beginning of the century, imposed by the Franco regime and transmitted by the Sección Femenina, ${ }^{8}$ before gradually being modified in the spirit of the social demands and the new post-1977 democratic reality in Spain.

\section{The different natures of women and men}

For twentieth-century Spanish conservatism, gender was based on the belief in two different natures: one female and the other male. This idea was established as an absolute truth and became the cornerstone of conservative thinking with regard to society and gender. It also served as a basis for the construction of a model for social organization that guaranteed discrimination against women and their subordination. The inspiration for this thinking was, among other sources, the postulates of Catholic social doctrine, in which inequality between women and men was firmly grounded, at least until the Second Vatican Council met in the first half of the 1960s. The encyclical issued by Leo XIII, Quod Apostolici Muneris in 1878 , asserted that 'the inequality of rights and of power proceeds from the very Author of nature [...] so also has he appointed that there should be various orders in civil society, differing in dignity, rights and power' (Noguer, 1923 pp. 290-306).

Throughout the century, this political culture equated women and men with different organs of a social body in which each nature was called upon to fulfil its own, different function. One example is Víctor Pradera, who combined the Catholic, traditionalist political inheritance with the modern organicist conception of society. His ideas, which were similar to those of some prestigious European intellectuals like the Krausist Heinrich Ahrens, were fortified by some of his own experiences. Pradera argued that society 'by its very nature belongs to the world of the organic'. Indeed, this author found the guiding principle of social life in the organism: 'the organic world postulates varied organs and different functions'. Consequently, 'a universal aspiration for equal rights between men and women among citizens [...] would result in social dissolution' (Pradera, 1932). Some 45 years later, in the midst of the transition to democracy, Manuel Fraga would continue to insist on this organicist idea of society, in which each sex is called upon to fulfil its 'natural' role.

Science became a source of inspiration for the construction of differences between the genders. The thesis of female inferiority based on phrenology, anatomy and physiology, and popularized by the works of Franz Joseph Gall, Herbert Spencer, Theodor von Bischoff and Karl Möbius, was replaced by the thesis of the difference 
between the sexes (Aresti, 1998). These new scientific explanations reached Spain quickly and were rapidly accepted by the more conservative political sectors. The ideas most often repeated in Spanish intellectual circles came from the work of Robby Kossman, which was inspired by evolutionist theory, and Georg Simmel's explanations regarding the differences between the sexes $(\mathrm{Be}-$ riain, 2000). Simmel argued that femaleness could be defined as a gender and could easily elude any definition as an individual. This thinking was echoed in Spain by José Ortega y Gasset, who asserted that 'woman is more of a gender than an individual' (Ortega y Gasset, 1947 p. 433, cited in Castillo, 2003). This argument quite closely mirrored those held by the Catalan Eugeni D'Ors and the Andalusian José María Pemán.

The central idea in Pemán's work was the difference and hierarchy between the sexes, and it was this author who best portrayed the image of feminity maintained by conservatism. His book, De doce cualidades de la mujer (On the Twelve Qualities of Women), included many of the impressions already printed in the weekly publication Ellas (She, (1932-1935), which he both founded and directed. He asserted that, as laid out in Genesis, the function of women was to be companions to their husbands and nurturers of their children, which is why God had not given them 'reason'. The function of men was creative activity and work, for which he required rational analysis (Pemán, 1947). ${ }^{9}$

Literature and propaganda also reproduced the old clichés about woman as the 'eternal minor' and her inferior intellectual capacity. ${ }^{10}$ For example, in an 1894 speech, Doctor Fernando Calatraveño discussed the inferiority of 'the woman' who 'can never be more than a woman, with her naivety, like that of an older child, her exaggerated nervous system, her extremely vivid imagination, her limited thinking, her innate coquetry'(Calatraveño, 1894, cited in Ballarín, 2001 p. 79). Philosopher and pedagogue Urbano González Serrano, in turn, based his arguments on biological determinism in order to combat any hint of egalitarianism in the education of women: 'neither education nor any philosophical principle can change the physiological nature of the sex [...] woman is woman; she is first and foremost the incarnation of love'. ${ }^{11}$

During the Franco dictatorship, these openly antifeminist ideas were transmitted across Spain through the Sección Femenina, the women's branch of the Falange political movement, and the Patronato de Protección a la Mujer, a public foundation established to ensure moral order, as a control mechanism. ${ }^{12}$ Moreover, despite the 'renewing' doctrine of the Second Vatican Council, the Church helped by insisting on the concept that domesticity was a woman's mission. These ideas were maintained by the AP. The party accepted equality - understood as legal equality between women and men - but the dualnature model survived. Although it was forced to make concessions for women, allowing them access to education (saying that it would benefit their children, who would be raised in a more cultured home) and to employment (when necessary for the family finances), and agree- ing to integrate women into its ranks (a propaganda move that gave it a modernizing image), the party never abandoned its ideological pillars related to gender (Félez, 2018).

During the transition to democracy, some changes had to be made in response to demands for equality from Spanish women. It was argued that the decision to work outside the home was as laudable as staying home as the 'pillar of family life' (AP, 1977 p. 10). For that reason, 'women's work at home' needed to be 'duly recognized' (Rodríguez, 1977 p. 59). For women who were forced to work outside the home, the AP proposed a 'specific work plan with a reduced schedule' $(\mathrm{CD}, 1979 \mathrm{p}$. 10) to respond to the obligations of married women. 'Pragmatic policies' were required to meet the specific needs of women, based on their 'womanly nature' (AP, 1981 p. 641). Recognition of 'women's work' was demanded, but there was no question that this work was to be done by women, despite the ideas held by members of the women's movement.

As a reflection of this new stance, one renowned member of the AP, Pilar Díaz-Plaja, averred that women after a certain age who had already raised their children could collaborate with their husbands 'in their companies, their work or whatever'. In no way, however, would this activity entail her abandoning 'her family duties and home' (Giráldez, 1978). Thus, without the burden on women inherent in reproduction, Spanish women were positioned as mere collaborators in public life.

\section{Women and anti-women, feminism and antifeminism}

One of the most important manifestations and reflections of modernity was the growing role of women in society (Thébaud, 2000). Women's suffrage and the possibility of participating in political activity arrived first with the Second Republic in the 1930s and then again with the establishment of the parliamentary monarchy in the last third of the twentieth century. Whether advantageous or not, the reality was, as José María Pemán said upon the proclamation of the Republic, that 'the vote has won women' (Pemán, $1932 \mathrm{p}, 6$ ). This was enough to force conservatives not only to reconstruct their proposed ideal of femininity, but also to construct a discourse capable of influencing women to vote for conservative parties, since they now represented more than half of the electorate. In light of this, the right was obliged to abandon their discussions about whether women leaving the home would 'bastardize their femininity' (Lis, 1932 p. 2). The only female deputy from the AP in the first two parliamentary terms insisted that rights for women remained to be won, but without this 'undermining their femininity' (Montejano, 1977). The party platform promised to fight for the 'current needs of Spanish women', but 'based on their female nature and without rejecting their traditional and spiritual values' (Alianza Popular, 1982 p. 87-88).

Two models of 'woman' were established. The first was the 'good' Mary and the second the 'odious' Eve, who had come to eliminate traditional gender roles and with that, terminate Western society as it was known. 
Women began to arouse contradictory feelings of surprise and confusion, due to their presence in spaces once reserved for men and their adoption of unexpected attitudes, a result of the social changes introduced that produced what came to be called 'gender uncertainty'. ${ }^{13}$ To alleviate this and preserve the traditional social structure, the two models of 'woman' were given content. There was the 'true Spanish woman', an ideal of traditional and patriarchal womanhood, illustrated by historical Spanish women considered illustrious, who were rescued and reconstructed (Ortega, 2010a). These women were presented as authentic, traditional examples of the essential values of 'eternal Spain' (Pemán, 1932). The figures evoked included Saint Teresa of Avila, Queen Isabella I and Joanna I of Castile. Other less well-known 'great and glorious women' were also exalted because of their many virtues and mercies with the lowly, their Christian femaleness, their spirituality, their cultured wisdom, their humility in greatness, their temperance in power, their modesty and austerity, and their determination in the face of adversity and the enemies of the Catholic religion. All of these heroines of the fatherland had forged an immortal and indestructible Spanish female type. ${ }^{14}$

The journal Ellas. Semanario de las mujeres españolas (She: A Weekly for Spanish Women) contained a section that linked the women of yesteryear to those of the moment by extolling figures with the same desirable features in the eyes of Pemán and the journal editors. The heirs to this spirit included Juana Salas, Pilar Careaga, Blanca de los Ríos and Mercedes Quintanilla, all notable representatives of the most important Catholic women's associations at the time. Like their predecessors, they were distinguished by their lucid intelligence, their noble Christian virtues, their roles as selfless daughters, wives and mothers and, finally, their efforts to pass down sound Spanish traditions and customs (Luzzatti, 1932 p, 1). This trend of exalting 'true Spanish women' was later continued by the heir to conservatism. Manuel Fraga not only commemorated these women, like Pilar Careaga, who he described as an exemplary, highly valuable and intelligent woman, ${ }^{15}$ but he also heaped praise upon other women that he considered as distinguished as their predecessors. These included the Countess of Campo-Alange, a woman who, in Fraga's words, was a 'writer of the truth about women' (Fraga, 1980 p. 56). He also mentioned Concepción Arenal ${ }^{16}$ as a notable author who knew how to take the postulates of Catholic social doctrine and put them into practice (Fraga, 2006 p. 254).

However, while the idea of a 'Spanish femininity' continued during the political transition, mentions of 'true Spanish women' disappeared from the official discourse, at least as they were spoken of in the early twentieth century. Given the challenges involved in establishing the democracy and shaping a new female democratic citizenship - understood not only as an expansion of rights and freedoms, but also as a broadening of spaces for women's participation and action (Radcliff, 2002 pp. 77-78) housewives were placed in that position instead. For AP, they became the new reference point for femininity, and the party sang their praises at the same time that it called for more recognition of their work, since they were 'the most important social force in Spain' for the right. The AP trusted them to 'maintain the spirit of the fatherland and order in our Spain and return common sense to our people' (AP Madrid, 1978 p. 4). The idea of regenerating the Spanish fatherland through true Spanish women housewives this time - lived on. ${ }^{17}$

The image of the 'anti-woman' or 'anti-Spanish women' constructed in the years prior to the Civil War also lived on. ${ }^{18}$ These anti-women were represented by females who had decided to participate in circles that had been exclusively male to that point. Some, who adopted the forms or manners of modernity and were known as garçonnes, were attracted to and supported feminism. The anti-women, then, became the negative version of 'true Spanish women'. They were riddled with horrible defects and symbolized vulgarity, sexual deviation, mannishness, heresy and revolution, and belonged to subversive, politicized groups. ${ }^{19}$ They were also credulous and naïve women, incapable of distinguishing between good and evil (Cernuda, 1932 p. 3), but also cold, calculating and lewd (Pérez, 1932a p. 9). Far from disappearing, this image was very much present during the transition period. The second feminist wave, represented by the women's liberation movement, was surprising because of its radicalism. The movement analysed the patriarchal system from all possible angles and - unlike the first feminist wave, which focused on conquering the public space and expanding citizenship rights for women - made the sexual revolution the benchmark of the era.

The response was not long in coming. AP warned of the need to design a specific, pragmatic and realistic policy that would respond to the requirements of 'Spanish women', based on protecting her female nature from being bastardized. Fraga was concerned about the new garçonnes of the 1970s. As he himself stated, 'the current trend of girls wearing "unisex" trousers, having short hair and using verbal violence with each other that is appropriate for young men is not a step forward'. In his opinion, the emancipation of women was 'a thing, and a very good one', but the feminism and 'anarchy' that came with it was a completely different matter (Fraga, 1976 p. 95).

Statements like this revealed the continuing persistence of the duality that had been constructed in the 1930s between 'real' Spanish women and enemies of the fatherland, but also between Catholic/humanist feminism and leftist feminism. The association made by Fraga about feminism and anarchy seemed to echo the past, when feminism was presented as an ally of communism and an anti-Spain that would end up destroying the family by separating women from domestic work and caretaking, leading them to public life and production. During the Second Republic, emancipation was considered a satanic desire, spread by socialists, anarchists, freemasons and Krausists with a single objective: to degrade the 'true woman' and destroy Christian civilization ${ }^{20}$ or seek 'social dissolution' at any cost (Pradera, 1932). Like Fraga would do later, deputy Diego María Crehuet y del Amo 
accused feminism of leading in its cardinal principles to anarchy' (Crehuet, n.d., 46). In the dying days of the Franco era, Manuel Fraga argued that the feminism of that time, which he called neo-feminism, was even worse than the feminism that emerged as part of the suffragist movement, since the earlier movement 'respected traditional ethical values', while the later movement 'sought to destroy them, and if that one was reformist, this one was deeply revolutionary' (Fraga, 1975 p. 39).

The party members of the AP argued in interviews that feminism was associated with negative connotations and unworthy of Spanish women. Carmen Fraga, the daughter of the party leader, was blunt in this respect: 'I am not a feminist, a hippy or a protestor' (Jiménez, 1977). Antonia Quiroga, the head of the AP's women and family section during the early years, defended some feminist ideas, but again with the proviso that this battle not keep women from maintaining 'their true feminine nature and their role within the family'. Moreover, in the defence of conservative or traditional femininity against 'radical' feminism, it was recommended that women's liberation be moderated when the woman 'does not have political or career aspirations or wish for a life outside the home; neither should she be forced to go out, if she is comfortable with her current status' (Aradillas, 1977). Carmen Llorca, who had been president of the Madrid Athenaeum, unambiguously linked the women's movement to violence in the presentation of her women's association: 'Feminist movements may have a different course, and also have a different strategy. Our strategy is non-violence' (Nieto, 1977). Similarly, they defended the division between 'good', 'humanist' or 'real' feminism reminiscent of the Catholic feminism at the beginning of the century, and 'bad' or 'radical' feminism represented by groups advocating the decriminalization of abortion (Aradillas, 1977). To some extent, these women could sympathize with feminism, but within limits when it came to questions related to 'female nature'.

\section{Conservatism and the family}

Conservatism considered the patriarchal family as the ideal institution to quiet the disquiet and trepidation generated by the new times. The social order depended on its stability, solidity, structure and hierarchized functions. If the difference between the sexes and traditional gender roles ceased to exist, society, too, would dissipate. This belief continued in the transition period, since 'civilizations die when the family disintegrates' (Anon., 1977 p. 6).

Arguments of this type can be found in the work of Francisco de Asís Pacheco. This prolific publisher and liberal politician from Andalusia was extremely well informed about the attention being paid by certain social sectors to the problem of women's equality. Convinced that the family constituted a social entity that preceded the individual and was a basic pillar of the state and value system of the "bien-pensant bourgeoisie, he showed no hesitation in presenting the threat inherent in any concession to the equality of the sexes: 'we trust that women's emancipation [...] will never become history. If it does, if we are mistaken, if our predictions do not come true, then, "Oh, what of the family!" In order to triumph, women's emancipation will have to pass over its dead body" (Asís, 1881 p. 36).

Between ultra-conservatives and traditionalists, women and the family were clearly part of the organicist philosophy of society and its religious foundation (Moya, 1984). This was the belief of Manuel García Morente, a Catholic philosopher who defended the family and the dichotomy of the sexes at any cost. For Morente, the family was 'a substantive entity, a distinct entity, independent and superior to the individuals who comprise it' (García, 1996 p. 113). The primary function of the woman, as daughter, was to 'maintain family cohesion', while the second was 'to maintain family continuity throughout the organism', or, in other words, to preserve tradition. This could only be done by women, since 'the essential principle of women is their warm and constant vocation. The father and brothers are the propellant element, those who bring the innovations; if you add your female innovations to those of your father and brothers, there will be no family continuity' (García, 1996 p. 114). As a wife, the woman was to subordinate herself to her husband, and her primary and only function was motherhood (García, 1996 p. 124).

Like the intellectuals who preceded him, Manuel Fraga saw a serious threat to the family in the scientific and technological advances and cultural and social changes taking place in the 1960s and 70s, with disastrous consequences. Since its constitution as a party, the AP defended the 'Christian conception of the family and its permanent values' (AP, 1977 p. 16). For the self-declared heir to sociological Francoism, the state had to protect the family, increasing 'due protection for this institution' (GODSA, 1976, 97-98).

In this battle to protect the traditional family, and despite being in the minority in Congress, Manuel Fraga introduced a bill on the Foundations of the Family in the Spanish State in the summer of 1980. The bill defined the family as a "permanent institution of natural law that guarantees the ordered perpetuation and integral development of the human species', in addition to stressing its function as the 'primary cell of the social organization' (BOE, 1980 p. 377). This definition of family only strengthened the traditional, Christian conception defended by the AP to that point. Men occupied the highest position in the hierarchy and, therefore, equality in the family continued to be unrecognized. In fact, the electoral propaganda appealed largely to the man as the head of the family: 'Family father, if you want security for you and yours, Act now! AP' (AP, 1977).

The conquest of rights by women in post-industrial societies and their entry into the labour force was, according to Fraga, a palpable reality that had allowed them to conceive of life in general in a very different way. This circumstance, however, had its counterpoint. All the political, social, cultural and technological innovation represented by the 1960s and 70s had led to the creation of 
'new problems for family unity and authority inside the family' (Fraga, 1959 p. 22). This paternal authority was in clear decline in the eyes of the AP leader and was due to the constant acceptance of egalitarian ideals (Folsom, 1934). The change in the family configuration and the new legal mechanisms extending across Europe were also responsible for 'the problems of women [...since...] the root cause is the explosion of the traditional family' (Fraga, 1959 p. 22). Specifically, the 'progress of divorce [...], the recognition of being unmarried as a normal state of life and aberrations related to sexual matters' had inaugurated a period of the 'systematic destruction of the family' (Fraga, 1959 p. 9). During the transition, divorce was a hobbyhorse for the political right, although the AP ended up accepting it when the debate over legalizing abortion entered the fray.

Conservatism continued to hold positions quite similar to those of the early twentieth century regarding the family, only giving in on divorce at the end of the century. ${ }^{21}$ The patriarchal family continued to be promoted, with a nucleus comprising a heterosexual marriage. Meanwhile, women, considered the pillar of the family throughout the century, focused on housework, nurturing and raising children and, generally speaking, reproduction. The discourse on domesticity continued to be found in the ideology of conservatism, as did the defence of a double nature or biological conditioning factors that made women more suitable for this type of work.

\section{CONCLUSIONS}

The twentieth century witnessed profound transformations. The visible modernization experienced in the world before and after World War II produced conflicting emotions. No-one could be indifferent to a world in constant change. The modernization of daily life and changes in customs, tastes and society were, on the one hand, attractive and seductive, but they also elicited a firm negative reaction. The decomposition of old values in the face of the rising equality of the sexes was expressed by many women and men in a form that was radical, urgent, intensely derogatory and exclusionary (Hobsbawm, 1995 p. 63). The astonishment and fascination with "modernity' was articulated in these people in the form of discontent, insecurity, fear and anxiety, at times producing critical, troubled world views about both society and the times. The inability to understand the meaning of the transformations taking place and the mistrust and trepidation about the advances that accompanied feminism were perceived by the conservative sectors of society as an irreversible tragedy as well as a threat.

The deep-rooted conception of femininity began to be called into question as social changes brought women into areas and spaces once exclusively reserved for men. Questions began to arise about what it meant to be a woman in the new times and circumstances, and questions were even asked about how far they could go, how close to equality without overreaching, straying into masculism and severely upsetting the social scripts heretofore assigned to the two sexes. When women won the right to vote and their status as full-fledged citizens was recognized, it exacerbated the male anxiety of the 1930s, as well as during the early years of the new democracy after the Franco dictatorship. The idea of a clash between women and men as a symbol of social contradictions would return time and again throughout the twentieth century, especially when it seemed that women were becoming increasingly present in traditionally male social spaces. All of this, along with the discontinuation of the classic emotional depiction of the sensitive, defenceless 'angel of the home' or 'romantic heroine', were experienced with a manifest sense of bewilderment as women took on unexpected attitudes and roles that had never been seen before. Resistance to women being granted full citizenship in democratic modernity came swiftly.

Consequently, the 'feminist controversy' was heated and constantly updated throughout the century. It attracted the attention of the conservative political spectrum, which did not hesitate to return to the principal axes of a classic, traditional, Catholic social school of thought that was unfavourable to women and their demands, all in an exercise aimed at countering women's grievances related to their social backwardness and presenting them as transgressive, disruptive, bold and defiant. In essence, they used arguments from medicine and the nascent social sciences from biologicist or cultural positions that saw the inferior nature and unequal social function of women with respect to men as fully established. The political platforms of the Spanish right in the twentieth century, then, had three core ideas: the double nature of women and men; a rejection of feminism; and the family as the ideal place for the women to engage in their 'natural' functions. Even as they had to adapt to developments like the passage of women's suffrage, Vatican II and the establishment of the parliamentary monarchy, the main positions were steadily held for almost an entire century.

These indelible markers of antifeminism did not, however, hinder resistance and debate inside the conservative parties that formed over time, which required a redefinition of the contents that characterized femininity within the Catholic conception. The agency of the "women of conservatism' was fundamental in this respect. This paper does not explore this idea -the reason being that the topic requires a much more extensive study- but many women did not accept being passive receptors for the discourse of the male members in their party at any time, despite what appears on the previous pages of this article. As far back as the most decisive years of the interwar period, Spanish women with links to Catholic Action wielded petitions that could well be endorsed by the feminist movement today. They advocated for improvements in the professional training of Spanish women, demanded jobs outside of the home, better salaries and working conditions, access to all educational levels, legislative and social reforms and so forth (Blasco, 2003), just as their counterparts did forty years later during the transition period.

Despite the antifeminist character of the general principles underlying the official discourse of the People's Al- 
liance, some of its members defended more progressive ideas than their colleagues, within limits. Indeed, some declared themselves to be feminists. Antonia Quiroga, called for legal equality, equal pay and opportunity, equal access to education and culture and women's political participation from what she called 'true feminism'. All of these women, including some who came to the party later, like Luisa Fernanda Rudi (Ferrer and Palma, 1996), had the same thing in common. While some declared themselves females but not feminists, others said that they were 'quiet' or 'humanist' feminists, and others directly supported the Catholic feminism embodied by the principles developed by Concepción Arenal. All of them, however, supported women's education, equal pay and equality before the law. Whether or not they were feminists, the opinions of these women paved the way in the party, which had to step back, reform and accept measures in their political discourse that ultimately fragmented the unitary identity that conservatism had constructed and projected onto women over the course of the twentieth century.

\section{NOTES}

1 Throughout the nineteenth century and until women won the vote in 1931, many and diverse arguments were put forward to exclude women from political rights, from the meaning of silence to the dictates of custom, from scientific theories based on prejudice to feelings practically devoid of reason. Above all, however, it was the desire to preserve sexual order in different political cultures, particularly liberalism. See Ortega (2010b) and Aresti (2012).

2 This feeling was widespread in Europe, North America and even Latin America, as examined in the following studies: Bard (2000); Bush (2007); Howard and Adams (1997); Trat; Lamoreux and Pfefferkorn (2006) and Echeverría (2005). For the American case, see Schreiber (2008).

3 Although antifeminist sentiments were always present, in an attempt to go beyond dichotomous views regarding the relationship between religion and modernity, some scholars have shown how identities did emerge within or close to some Catholic associations that permitted a movement articulated around modern concepts of sexual difference and subjects that were self-reflexive and to some extent secularized. For the early twentieth century, see Blasco (2017). For the Franco dictatorship, see Valiente (2016) and de Moreno (2003).

4 A genealogy of conservative thought and its different trends, including the conservatism that dominated during the transition to democracy, can be found in González (2016).

5 Fraga observed of Pemán: 'the patriarch José María Pemán honours us by accompanying us in the presidency'. This was not the only occasion on which the 'patriarch' of conservatism was present at the meetings of the People's Alliance: Fraga (1987) pp. 82 and 258. On the friendship between Manuel Fraga and José María Pemán, see Fraga (1988).

6 For a more in-depth look at early twentieth-century conservative thinking and its conception of women, see Ortega (2008; 2010 and 2011).

7 The transition-era Union of the Democratic Centre (UCD) is not included here. Despite containing some conservative subgroups, the women in the party and the successive governments were open to advancing the rights of women, for example, during the controversy surrounding the divorce law. See Gunther \& Hopkin (2002, pp. 191-232). As shown by Félez (2018), the leading figures - both women and men - behind the measures in favour of equal rights between women and men, both in the party and in the General Subcommittee on Women's Affairs, were members of the social-democratic sectors of the UCD who later left politics or joined the PSOE.

8 Much has been written about the Falange's Sección Femenina. One recent and novel approach is found in the article by Cenarro (2017).

9 See also Scanlon (1976) and Álvarez (1996) for further development of the topic.

10 Sánchez has identified the women's publications, both progressive and conservative, in Spain in the nineteenth and twentieth centuries. See her article (Sánchez, 2009, pp. 217-244, p. 223 and ff.). On the publications written for women and their contents, see the article by Rebollo \& Núñez (2007), pp. 181-219.

11 This quotation from González comes from a book he wrote with Adolfo González (1893).

12 See the bibliography on the Franco period and, specifically, the Sección Femenina. See Primo de Rivera (1983); Martínez (2003); Cuesta (2003); Arribas, Juan Carlos et al. (2008) and López (2004).

13 This feeling was widespread in Europe, North America and even Latin America, see Bush (2007); Howard \& Adams (1997).

14 This appears in Anonymous (1932) Ellas. Semanario de las mujeres españolas, 20, p. 4. Also in Number 22, p. 2.

15 Something that he repeats in Fraga (1980), p. 245 and (1987), p. 152.

16 Cited by Antonia Quiroga, the head of the AP's women and family section during the transition, as a reference point. See A. Aradillas (1977).

17 The regenerative nature of women was discussed, for example, in A. Goicoechea (1922). See Blasco (2013) and the cited works by Ortega.

18 This image was created by the leaders of the main anti-Republican organizations in their propaganda. The speeches of women like Pilar Careaga, Teresa Luzzatti, Juana Salas and Rosa Urraca Pastor are well known. All of these women opposed the equality discourse of the women's movement. For Teresa Luzzatti and Rosa Urraca Pastor, feminists were inspired by the leftist ideology becoming established and were, thus, joining forces with 'the repugnant Red Lady'. See Luzzatti (1932) and Urraca (1932).

19 These prejudices began with the suffragettes and continued to be in vogue during the Franco period and transition. On the 1930s, see Aguado and Ortega (2011 pp. 173-206). For the Franco period, see Joly $(2008,95)$.

20 In the words of the Jesuit Julio Alarcón y Meléndez: 'The feminist movement, which does not comply with the impulse of God, but of Satan, begins by provoking laughter and ends by provoking horror'. Alarcón (1908, pp. 38-39).

21 See the controversy surrounding divorce in Félez (2018).

\section{REFERENCES}

Aguado, Ana y Ortega, Teresa María (Eds.) Feminismos y antifeminismos: culturas politicas e identidades de género en la España del siglo $X X$. Valencia, PUV.

Alarcón, Julio (1908) "Un feminismo aceptable". Razón y Fe, pp. 38-39.

Alianza Popular (1977a) Qué es Alianza Popular. Manifiesto de Alianza Popular. Madrid: AP.

Alianza Popular (1977b) "Por la emancipación de la mujer". Alianza Popular: especial elecciones, 10.

Alianza Popular (1977c) "Padre de familia" Hoja del Lunes, 23 de mayo.

Alianza Popular (1981) Libro Blanco: Soluciones para una década II. Madrid: AP.

Alianza Popular (1982) Es hora de soluciones. Programa de gobierno. Madrid: AP.

Alianza Popular Madrid (1978) Boletín informativo de Madrid, 4.

Álvarez, Gonzalo (1996) José María Pemán. Pensamiento y trayectoria de un monárquico (1897-1941) Cádiz: Servicio de Publicaciones de la Universidad de Cádiz. 
Anónimo (1977) "Nuestra Gran Familia”. Alianza Popular: especial elecciones, 4

Aradillas, Antonio (1977) "Los partidos políticos y la mujer 2: Alianza Popular: Preponderancia ante los hijos. Entrevista a Antonia Quiroga de Abeijón". Pueblo, 28 de abril.

Arce, Rebeca (2005) "De la mujer social a la mujer azul". Ayer. 57 (1) pp. 247-272.

Aresti, Nerea (2012) "Los argumentos de la exclusión. Mujeres y liberalismo en la España contemporánea". Historia constitucional: Revista Electrónica de Historia Constitucional, 13

Arribas, Juan Carlos et al. (2008) "La labor formativa desarrollada por la Sección Femenina de la Falange en la preparación de sus mandos e instructoras durante el período franquista". Historia de la Educación. 27 pp. 347-365.

Ballarín, Pilar (2001) La educación de las mujeres en la España contemporánea, (siglos XIX-XX). Madrid: Síntesis.

Bard, Christine (2000) "Para una historia de los antifeminismos". In Bard, C. (Ed.) Un siglo de antifeminismo. Madrid: Biblioteca Nueva, pp. 25-39.

Beriain, Josetxo (2000) "El ser oculto de la cultura femenina en la obra de Georg Simmel”. Revista Española de Investigaciones sociológicas. 89 pp. 141-182.

Blasco, Inmaculada (2003) Paradojas de la ortodoxia. Política de masas y militancia católica femenina en España (1919-1939). Zaragoza: Prensas Universitarias de Zaragoza.

Blasco, Inmaculada (2013) "Mujeres y nación: ser españolas en el siglo XX”. In Moreno, J. and Núñez, M. Ser españoles. Imaginarios nacionalistas en el siglo $X X$. Barcelona: RBA.

Blasco, Inmaculada (2017) "Identidad en movimiento: la acción de las «católicas» en España (1856-1913)". Historia y política: Ideas, procesos y movimientos sociales. $37 \mathrm{pp}$. 27-56.

Bolufer, Mónica (1998) Mujeres e Ilustración. La construcción de la feminidad en la España del siglo XVIII. València: Institució Alfons el Magnànim.

Bourdieu, Pierre (2007) El sentido práctico. Buenos Aires, Siglo XXI.

Bush, Julia (2007) Women Against the Vote: Female Anti-Suffragism in Britain. Oxford: Oxford University Press.

Cabrera, Miguel Ángel (2006) "Lenguaje, experiencia e identidad. La contribución de Joan Scott a la renovación teórica de los estudios históricos" In Borderías, C. (Ed.) Joan Scott y las politicas de la historia. Barcelona: Icaria.

Castillo, Marcia (2003) "La "fémina insurgente": personaje femenino y modernidad en la vanguardia española de los años veinte". Espéculo: Revista de Estudios Literarios, 23.

Cenarro, Ángela (2017) "La Falange es un modo de ser (mujer): discursos e identidades de género en las publicaciones de la Sección Femenina (1938-1945)". Historia y Política. 37 pp. 91-120.

Cenarro, Ángela and Illion, Regina (Eds.) (2014) Feminismos. Contribuciones desde la historia. Zaragoza: Prensas de la Universidad de Zaragoza.

Cernuda, María Teresa (1932) "Deberes de la mujer". Ellas. Semanario de las mujeres españolas, 16.

Coalición Democrática (1979) Un programa de gobierno de centroderecha. S.1.: CD.

Crehuet, Diego María (n.d.) El feminismo en los aspectos jurídicoconstituyente y literario. S.1.: Editorial Reus.

Davidoff, Leonore and Hall, Catherine (1994) Fortunas familiares. Madrid: Cátedra.

Echeverría, O. (2005) "Los intelectuales antidemocráticos argentinos en las primeras décadas del siglo XX: la exclusión de género como uno de los fundamentos de la definición autoritaria". Signos Históricos, 13, pp. 120-149.

Félez, Nuria (2018) Discurso de género e implementación de politicas de género en los partidos políticos de la derecha española durante la transición y hasta 1989 en perspectiva comparada. Tesis doctoral. Granada: Universidad de Granada.

Ferrer, Pilar and Palma, Luisa (1996) Ellas son así. Retrato íntimo de las mujeres del poder. Madrid: Temas de Hoy.

Folsom, Jeanette K. (1934) The family and demoratic society. Nueva York.

Fraga, Manuel (1959) La familia española ante la segunda mitad del siglo XX. Madrid: Cuadernos de Investigación.
Fraga, Manuel (1975) La mujer y la política. Conferencia pronunciada en el Ateneo de Madrid.

Fraga, Manuel (1976) Cánovas, Maeztu y otros discursos de la segunda Restauración. Madrid: Sala Editorial.

Fraga, Manuel (1980) Memoria breve de una vida pública. Barcelona: Planeta.

Fraga, Manuel (2006) Sociedad y valores. Barcelona: Planeta.

Fraser, Nicholas (2001) The voice of modern hartred. Encounters with Europe's new right. London: Picador.

García, Manuel (1996) Obras completas II (1937-1942). Vol II. Barcelona: Anthropos.

Giráldez, E. (1978) "Pilar Díaz-Plaja, presidente de la Confederación de Mujeres Empresarias" El Alcázar, 12 de junio.

GODSA (1976) Libro Blanco para la Reforma Democrática. Madrid: GODSA.

Goicoechea, A. (1922) El feminismo político y el influjo social de la mujer (Conferencia pronunciada en Barcelona el 16 de diciembre).

Gunther, Richard and Hopkin. Jonathan (2002) "A Crisis of Institutionalization: The Collapse of the UCD in Spain". In Gunther; Montero and Linz (Eds.): Political Parties. Old concepts and New Challenges. Oxford: Oxford University Press: 191-232.

Hobsbawm, E. (1995) Historia del siglo XX, 1914-1991. Barcelona: Crítica.

Howard, Angela and Adams, Sasha Ranas (1997) Redefining the New Woman, 1920-1963 Antifeminism in America: A Collection of Readings from the Literature of the Opponents to U.S. Feminism, 1848 to the Present). New York: Garland Pub.

Jiménez, M. (1977) "El feminismo incomprendido" Informaciones, 22 de junio.

Joly, Maud (2008) "Las violencias sexuadas de la guerra civil española: paradigma para una lectura cultural del conflicto". Historia Social, 61 .

Lis, B. (1932) "Mujeres de hoy. Doña Juana Salas de Jiménez”. Ellas. Semanario de las mujeres españolas, 6.

Luzzatti, Teresa (1932) "El deber de las mujeres en la hora presente exige unión y decisión”. Ellas. Semanario de las mujeres españolas, 5.

Martínez, E. (2003) "Movilización femenina antifeminista en el franquismo. La Sección Femenina del Movimiento". In Cuesta, J. (Dir) Historia de las mujeres en España. Siglo XX. Vol. 2. Madrid: Instituto de la Mujer.

Montejano, Irene (1977) "Una periodista en el Congreso". $A B C, 13$ de julio.

Moreno, Mónica (2003) "De la caridad al compromiso: las mujeres de Acción Católica (1958-1968)". Historia contemporánea. 26 pp. 239-265.

Moya, Carlos (1984) Señas de Leviatán. Estado nacional y sociedad industrial: España 1936-1980. Madrid: Alianza.

Nieto, Miguel (1977) "Carmen Llorca. Presidenta de la Organización de Mujeres Independientes”. Pueblo, 18 de febrero.

Noguer (1923) "La primera encíclica de Pío XI y el modernismo social" Razón y Fe. 65 pp. 290-306.

Ortega, Teresa María (2008) "La mujer en los discursos del autoritarismo y el fascismo (1914-1936)". Ayer. 71 pp. 53-83.

Ortega, Teresa María (2010a) "Culturas liberales y catolicismo en la génesis del antifeminismo franquista”. Historia Social. 67 pp. 155-171

Ortega, Teresa María (2010b) “"Hijas de Isabel” Discurso, representaciones y simbolizaciones de la mujer y de lo femenino en la extrema derecha española del periodo de entreguerras". Feminismo/s. 16 pp. 207-232.

Ortega, Teresa María (2011) "¡Cosa de coser ... y cantar! La derecha antiliberal y el adoctrinamiento político de la mujer de clase media en la Segunda República”. In Aguado, Ana and Ortega, María Teresa Feminismos y antifeminismos. Culturas políticas e identidades de género en la España del siglo XX. València: PUV. pp. 173-206.

Pacheco, Francisco de Asís (1881) La misión de la mujer en la sociedad y en la familia. Madrid: Gaspar.

Pemán, José María (1932) "Las mujeres y las costumbres”. Ellas. Semanario de las mujeres españolas, 2. 
Pemán, José María (1932) "Voto e ideas". Ellas. Semanario de las mujeres españolas, 1.

Pérez, H. (1932a) "Emancipada, pero...". Ellas. Semanario de las mujeres españolas, 26.

Pérez, H. (1932b) "Feminidad II" Ellas. Semanario de las mujeres españolas, 27 de julio.

Pradera, V. (1932) "Feminidad". Ellas. Semanario de las mujeres españolas, 19 de junio.

Primo de Rivera, Pilar (1983) Recuerdos de una vida. Madrid, Dyrsa.

Radcliff, Pamela (2002) "Citizens and housewifes: the problem offemale citizenship in Spais's transition to democracy". Journal of Social History, 36.

Ramos, María Dolores (2010) "Las primeras modernas. Secularización, activismo político y feminismo en la prensa republicana: Los Gladiadores (1906-1919)”. Historia Social. 67 pp. 93-112.

Rebollo, María José and Núñez, Marina. (2007) "Tradicionales, rebeldes, precursoras: instrucción y educación de las mujeres españolas a través de la prensa femenina (1900-1970)". Historia de la Educación. Revista Interuniversitaria. 26 pp. 181-219.

Rodríguez, R. (1977) Alianza Popular. Málaga: Lafer.

Rodriguez López, Sofía (2004). "La falange femenina y construcción de la identidad de género durante el franquismo". In Actas del IV Simposio de Historia Actual: Logroño, 17-19 de octubre de 2002. La Rioja: Instituto de Estudios Riojanos. pp. 483-504. Sánchez, María F. (2009) "Evolución de las publicaciones femeninas en España. Localización y análisis". Documentación de las Ciencias de la Información. 32 pp. 217-244.

Scanlon, Geraldine (1976) La polémica feminista en la España Contemporánea: 1868-1974. España: Siglo XXI.

Schreiber, Ronee (2008) Righting Feminism. Conservative Women \& American politics New York: Oxford University Press.

Scott, Joan W. (1988) "Deconstructing equality-versus-difference: or, the uses of postestructuralist theory for feminism". Feminist Studies- 14 (1) pp. 33-50.

Thébaud, Françoise (2000) "La Primera Guerra Mundial: ¿la era de la mujer o el triunfo de la diferencia sexual?". In VV.AA. Historia de las mujeres en occidente (5). El siglo XX. Madrid: Taurus.

Trat, Josette; Lamoureux, Diane and Pfefferkorn, Roland (Dirs.) (2006) L'autonomie des femmes en question: antiféminismes et résistances en Amérique et en Europe. Paris: Harmattan.

Urraca, R. M. (1932) “La necesidad del sacrificio". Ellas. Semanario de las mujeres españolas, 23.

Valiente, Celia (2016) "Luchar por participar: la protesta feminista en la Iglesia Católica durante el franquismo". Pasado y Memoria. Revista de Historia Contemporánea. 15, 2016 pp. 203-222. 